\title{
Waste investigation on product development process using the lean and simulation approaches
}

\author{
Eduardo G. Salgado ${ }^{a}$, Carlos Henrique Pereira Mello ${ }^{b}$, Fabiano Leal ${ }^{b}$, Carlos Eduardo Sanches da Silva ${ }^{b}$ \\ aFederal University of Alfenas \\ bFederal University of Itajubá \\ e-mails: egsalgado@yahoo.com.br; carlos.mello@unifei.edu.br, leal@unifei.edu.br; sanches@unifei.edu.br
}

\begin{abstract}
The product development process (PDP) has become increasingly critical to the competitivity of enterprises due to the growing international market, the increasing variety and diversity of materials and the reduction of product lifetime. The present work has as its main goal to identify wastes within the PDP. The methodological approach used was the quali-quantitative, along with an exploratory outline and a taxonomy development model. Initially, a qualitative approach is used in this model, through a case study, in order to identify enterprise waste in the PDP. Secondly, a quantitative approach is then, performed through simulation in order to evaluate possible gains as result of these waste mitigations or eliminations. The analysis unit selected for this research was a multinational enterprise in Brazil. This enterprise develops holders used on test tables for wire harnesses, which has short, medium and long product development cycles. Results showed that Value Stream Mapping is an appropriate tool to building current and future state mapping used in identifying PDP wastes. Moreover, the simulation of mitigation or elimination of identified waste showed that the studied enterprise could obtain gains in the order of $12 \%$ the amount of developed hoders.
\end{abstract}

Keywords: product development; lean thinking; lean development; value stream; process mapping; waste elimination.

\section{Introduction}

Wheelwright and Clark (1992) at the beginning of last decade claimed that PDP is an excellence factor, as well as the operational efficiency, which seeks to minimize wastes.

The scientific approach to lean thinking was initially introduced by Womack, Jones and Roos (1992), Shingo (1996), Womack and Jones (2004) and Hines, Holweg and Rich (2004), and, eventually, transported to the product development process. Sohal and Egglestone (1994), Karlssson and Ahlström (1996), Bauch (2004) and Machado (2006) focused on the evaluation of the lean thinking potentialities in the areas of research and development, verification of implementation difficulties of lean development, waste proposition for lean development and finally a procedure to implement lean thinking in the PDP, following project structure, respectively. The research works, previously cited, mention the value stream mapping as a tool to identify PDP wastes. However, they have only a theoretical approach, while the present work contributes with an empirical application.

Based on what was just exposed, one comes to know that identification and mitigation of waste factors (time, useful activities, reworks etc) in the PDP may reduce the lead-time in this process and then, may bring a competitive advantage to the enterprise. The present research has an applied nature, since it aims to obtain practical results concerning the waste mitigation impact in the product development process of an enterprise. It has exploratory goals, once the theme, the lean approach in the product development is still incipient in the scientific literature.

The approach used in this work is the combined one that, according to Creswell and Plano Clark (2007), encompasses philosophic thoughts that guide data analysis and collection, and the combination of the qualitative and quantitative approaches in only one study or in a series of studies. The premise of this approach is that the combined use of qualitative and quantitative approaches offers a better understanding of the research problems than when they are separately concerned.

The kind of outline used is the exploratory one, where the results from a first qualitative method help develop or collect information for the second quantitative method (CRESWELL; PLANO CLARK, 2007). Within this outline, it was used a taxonomy development model. This model was chosen for it has an initial qualitative stage that is carried out in order to identify important variables or to develop an emergent theory and a second quantitative stage that 
tests or studies these results in more details (CRESWELL; PLANO CLARK, 2007).

For the qualitative part of this model, a case study method was adopted. According to Yin (2005), such investigation faces a solely technical situation where there will be many more variables of interest than data points and, as a result, it is based on many evidence sources. Therefore, the data must converge to a triangle format (considering triangulation as a means of collecting data from theory, empirical evidence and from the researcher's contribution); and as another result, it benefits from the theoretical propositions in order to conduct data analyses and collection.

This method was adopted because it is the most indicated for exploratory research, aiming to answer the following research question: What are the lean approach wastes that influence in the product development process? How are these wastes identified?

In order to answer the questions above, the main goal of this work is to identify wastes within the PDP of an enterprise. The secondary goals are: to analyze the PDP lean thinking fundamentals that contribute to reduce wastes; to recommend actions with basis on the lean thinking to reduce wastes in the PDP; to analyze the PDP waste reduction impact through simulation in terms of concluded developments; and to analyze the value mapping contribution to the PDP waste identification.

To achieve these goals, an exploratory literature review was initially performed to identify pertinent variables and to raise the main wastes inherent to PDP, as well as, the tools that may give support to the reduction or elimination of such wastes. Later, It was performed a case study in a multinational enterprise, with its headquarters in Brazil, in order to analyze the stream value mapping application in its PDP. Interview techniques, document analysis and direct observing processes were used to collect data. The key-interviewees in the PDP were the ones in charge of the project and sales department, the computer-aided manufacturing area (CAM), as well as, all the project sector staff.

\section{The product development process (PDP)}

Recently, some authors such as Loch and Terwiesch (2007), Durmuşoğlu and Barczak (2011), defined PDP as the process responsible for new products along their life cycles. It encompasses their strategic and technical conception, the product process and project, its market launch, its followup tracking and enhancement in its manufacturing and marketing, its discontinuity and market withdraw, as well as its availability after its use.

Improving the NPD performance is the focus of many researches such as Yeh, Pai and Yang (2008), Rundquist and Halila (2010), Chiang and Che (2010), Panizzolo, Biazzo and Garengo (2010), Park (2010), Salgado, Salomon and
Mello (2012), Samaan et al. (2012), Silva et al. (2013). Thus, proposals for new methods, tools, strategies, techniques, and so on, are developed and employed in the NPD management in order to reduce costs and product development time, to enhance quality and manufacturing, etc.

NPD may be considered of difficult visualization for it has a complex management, dynamic nature, great interaction with the enterprise remaining activities and the amount of information dealt with during a new product development.

Literature review shows that authors use different views to approach the PDP. However, it is observed that most of the stages are repeated and many vary only in the terminology adopted (BACK, 1983; ROSENTHAL, 1992; VINCENT, 1989; WHEELWRIGHT; CLARK, 1992; COOPER; EDGETT, 1999; PAHL et al., 2007; ROZENFELD et al., 2006).

Researches carried out by Rozenfeld et al. (2006) pointed to the existence of various approaches to the PDP. Among all, one of the most cited in the literature is the PDP lean approach, also known as lean development. It brings contributions: a more organic view of the process achieved, through the maximum simplification of the work of teams involved in PDP, focusing on prototyping and test activities; the possibility of delaying, to the maximum extent, very specific detailed decisions since the time spent on such activities, should be invested in seeking alternative solution and understanding of project problem.

\section{Lean thinking}

According to Hines, Holweg and Rich (2004), the lean thinking application has caused a significant impact in the academic and industrial circles over the last decade. There was a development of the lean thinking due to a fast propagation in many industrial sectors, besides the automotive.

According to Womack and Jones (1996), the lean thinking is a way to specify value; line up in the best sequence, the actions that create value, perform these activities without interruption every time one claims them, and accomplish them in a more efficient way. In sum, the lean thinking is a way of doing even more with even less, that is, less human effort, equipment, time and space, and at the same time, meeting even more accurately the clients' needs. Thus, the basis of this thought is to identify and eliminate wastes, that is, everything that do not add value to the client.

The significant growth of lean thinking application in organizations occurred due to its new design, validated by its results. Concomitantly, the lean approach came to be the theme of many studies (HINES, HOLWEG; RICH, 2004; FEARLE; FOWLER, 2006; KEMPTON, 2006; PETERSEN; WOHLIN, 2010; DEMETER; MATYUSZ, 2011; PAPADOPOULOS, RADNOR; MERALI, 2011). 
Womack and Jones (1996) established five principles to the lean thinking for the entire enterprise: Value, stream value, stream, pull production and perfection.

The lean value conceptual thought is to eliminate wastes within enterprises. According to Ohno (1988), waste refers to every element of production that does not aggregate value to the product, from the standpoint of the client, but that is held within the production process. Shingo (1996) considers that the seven wastes to the Toyota Production System (TPS) are Overproduction; Waiting; Excessive Transportation; Inadequate Processes; Unnecessary Inventory; Unnecessary Movement and Malfunctioning Products.

Knowing that the lean thinking may be used in every enterprise process, it may become a PDP approach. Besides those seven wastes found by Shingo (1996) for the lean thinking, Bauch (2004) proposed three other wastes for the PDP:

- Reinvention: wastes can be found whenever trying to reinvent processes, solution methods and products that already exist or that should only need a few modifications to become adequate to a given problem;

- Lack of discipline: waste lies in not well-defined objectives and scopes, roles, responsibilities and rights which are not declared or informed, not welldefined rules, dependency, poor definition among activities, insufficient predisposition to cooperate, incompetence or poor training;

- Integration of information technology (IT): the great component variety of IT (hardware, software, nets, etc.) and the challenge of mapping all the development process in an integrated way that makes it possible not only to up-to-date tools, but also to future ones, leads to problems of low compatibility, capability and availability.

Chart 1 shows a comparison between waste definitions for manufacturing and its adaptation to the product development process.

According to Bauch (2004), product development is different from manufacturing, since it may be understood, as some kind of information creation developer: create information, collect, evaluate and reduce risk and uncertainty, and at the same time to develop gradually a new product without failures that can be used at the plant. On the other hand, the manufacturing goal is to reproduce exactly the same product repeatedly and without failures, depending on the industrial sector that may vary in value between dozens and hundreds of thousand ways.

\section{Simulation}

According to Pereira (2000, p. 02),

computational simulation is the real system representation through a model that uses computers. It brings the advantage of being able to visualize this system and answering what-if questions saving time and money".
Similarly, Law and Kelton (1991) claim that the benefit of simulation is that it allows the engineer or manager to obtain a systemic view of the effect that local changes will have upon the overall performance of the entire production system. Some other benefits cited by the author are a higher use of required resources, reduction of work in process, higher speed and delivery reliability, lower operating costs, higher understanding of the system, and better consideration of certain aspects of the production system. This is all due to the construction of the model.

This quantitative method was adopted in order to confirm the following hypothesis: mitigation of wastes brought about in product development process favors the increase on the number of developed products.

The simulation model was developed according to the steps suggested by Gavira (2003): to formulate the problem and the study planning, to collect data and define the model, to validate the model, to build the computational code, to verify the results, to conduct pilot testes, to validate the programmed model, to project the experiments and to conduct a simulation execution.

To validate the models, Sargent (2004) describes several techniques in literature that may be used in subjective and objective ways. Some of these techniques are animation, comparison with other models, degenerative tests, event validity, and extreme condition, validation through historical data, internal validity, multi-stage validation, operational graphics and life tests among others.

According to Kleijnen (1995), the computational model validation may be done using the following:

$$
\left(\overline{\mathrm{X}_{\mathrm{s}}}-\overline{\mathrm{X}_{\mathrm{r}}}\right) \pm \tau_{2 \mathrm{n}-2, \alpha / 2} * \sqrt{\frac{\mathrm{S}_{\mathrm{s}}^{2}+\mathrm{S}_{\mathrm{r}}^{2}}{\mathrm{n}}}
$$

Where:

$X_{s}$ - Average of simulated results

$\mathrm{X}_{\mathrm{r}}$ - Average of real results

$\mathrm{S}_{\mathrm{s}}$ - Standard deviation of simulated data

$\mathrm{S}_{\mathrm{r}}$ - Standard deviation of real data

$\mathrm{n}$ - Sampling data number

$\tau_{(2 \mathrm{n}-2)}$ - Degrees of freedom

$\alpha / 2$ - Significance level (Distribution $t$ table -appendix).

In order to validate the model, the range obtained with the expression [1] should include the value zero. It is worth mentioning that the simulation requires additional data so that a dynamic analysis of the system can be carried out (GREASLEY, 2003), which may be obtained by means of process mapping, researchers'observations, record analysis, interviews and questionnaires.

According to Paço (2006), it is possible to use the computational simulation as a tool to help in the value stream mapping, giving then a dynamic mapping. Thus, the mapping will be done on the present and future state, in the 
Chart 1. Relationship between wastes from product development process and manufacturing.

\begin{tabular}{|c|c|c|c|}
\hline & Waste & Manufacturing & Product development \\
\hline \multirow{5}{*}{1} & \multirow{5}{*}{ Waiting } & Material and operation parts & Available human or machine capacity \\
\hline & & Maintenance & Information waiting for people \\
\hline & & Tools & \multirow{3}{*}{$\begin{array}{l}\text { Waiting for data, answers, requirements, specifications, test } \\
\text { results, approvals, decisions, review sections, signatures }\end{array}$} \\
\hline & & Operators & \\
\hline & & Queue for further operations & \\
\hline \multirow{3}{*}{2} & \multirow{3}{*}{ Transport } & $\begin{array}{c}\begin{array}{c}\text { Excessive movement of pieces, materials, pieces } \\
\text { and products }\end{array} \\
\end{array}$ & Excessive data trade \\
\hline & & Storage movement & The comes and goes of tasks or of interrupted tasks \\
\hline & & Insertion or withdraw of material/product/piece & Inefficient communication \\
\hline \multirow{3}{*}{3} & \multirow{3}{*}{$\begin{array}{l}\text { Unnecessary } \\
\text { movement }\end{array}$} & \multirow{3}{*}{$\begin{array}{l}\text { Operators' minimum movements (reach, bend, } \\
\text { force) }\end{array}$} & Remote places \\
\hline & & & Information search \\
\hline & & & Direct access lack \\
\hline \multirow{6}{*}{4} & \multirow{6}{*}{$\begin{array}{l}\text { Inadequate } \\
\text { processes }\end{array}$} & \multirow{3}{*}{$\begin{array}{l}\text { Over-dimensioning of process, machines and } \\
\text { equipment }\end{array}$} & Unnecessary precision and details \\
\hline & & & Unnecessary features and processes \\
\hline & & & Inadequate competence use \\
\hline & & \multirow{3}{*}{$\begin{array}{c}\text { Unnecessary accuracy of product or process, not } \\
\text { meeting the client's real needs }\end{array}$} & Inappropriate use of tools and methods \\
\hline & & & Excessive accuracy \\
\hline & & & Excessive transactions \\
\hline \multirow{3}{*}{5} & \multirow{3}{*}{ Inventory } & $\begin{array}{l}\text { Excessive raw-material storage, semi-finished } \\
\text { products compared to the client's demands }\end{array}$ & Excessive data storage \\
\hline & & Waiting lines & Unnecessary prototype and equipment tests \\
\hline & & Storage among operations & Waiting lines in a critical path \\
\hline \multirow{4}{*}{6} & \multirow{4}{*}{ Overproduction } & \multirow{2}{*}{ To produce more than the client's order } & Low synchronism of solicited time and capacity \\
\hline & & & Low synchronism of considered content \\
\hline & & \multirow{2}{*}{ To produce before the client's order } & Excessive information dissemination \\
\hline & & & Task redundancy \\
\hline \multirow{3}{*}{7} & \multirow{3}{*}{ Defects } & $\begin{array}{l}\text { Components, materials, sub-assembling or } \\
\text { products that do not have required quality }\end{array}$ & Information with deficient quality \\
\hline & & Production internal defects & Wrong database and information \\
\hline & & Supplying defects & Poor tests and verifications \\
\hline \multirow{2}{*}{8} & \multirow{2}{*}{ Reinvention } & \multirow{2}{*}{ Not applicable } & Project poor reuse \\
\hline & & & Knowledge poor reuse \\
\hline \multirow{6}{*}{9} & \multirow{6}{*}{ Lack of discipline } & \multirow{6}{*}{ Not applicable } & Not well done objectives and goals \\
\hline & & & Badly defined roles, responsibilities and rights \\
\hline & & & Badly elaborated rules \\
\hline & & & Poor dependency definition among activities \\
\hline & & & Insufficient predisposition to cooperate \\
\hline & & & Incompetence or poor training \\
\hline \multirow{3}{*}{10} & \multirow{3}{*}{$\begin{array}{l}\text { IT resource } \\
\text { limitations }\end{array}$} & & Poor compatibility \\
\hline & & Not applicable & Poor capacity \\
\hline & & & Low capacity \\
\hline
\end{tabular}

Source: Bauch (2004).

product development process with a following verification on product development enhancement since the PDP waste elimination is verified.

Finally, in this work, the qualitatively and quantitatively collected data were interpreted, analyzed and discussed, providing an opportunity to answer the research questions and to test the hypothesis that with the elimination of waste, the enterprise will develop more products.

\section{Empirical research}

\subsection{Analysis unit selection}

The investigation unit selected for the case study is a small multinational enterprise in the automotive product market, producing Ring out Boards (ROB). These tools are responsible for the execution of continuity tests, sealing and 
wire harnesses, identifying failure, its position and printing labels and records. They are tools of high aggregated value for they use software technology, which is pneumatic, electronic, electric and optical. The wire harnesses are the second most expensive vehicle component, just staying behind the motor itself. EMDEP Brazil Ltda also has plants in Spain, Mexico, and Morocco and is located in the city of Itajuba, Minas Gerais State, Brazil. The reason for choosing this enterprise was that it has in its ISO 9001:2000 certification, the product development process that favors the existence of a systematic model for PDP; and it is a representative case for it develops products with short, medium and long development cycles, favoring the polar cases study.

The electrical approval is the test of all circuits belonging to the product in order to ensure its physical integrity and meet the client's requests concerning the correct positioning of circuits. On the other hand, the component approval consists of testing any auxiliary component that is aggregated to the client's product such as gaskets, grommets, clips, caps, capes, bags, chutes, among others.

Each product requested by the client needs to be developed, that is, the client provides a sample through which a PDP is initiated, so EMDEP works in the

Chart 2. Characterization of wastes identified in the case study.

\begin{tabular}{|c|c|c|c|c|c|}
\hline \multicolumn{2}{|c|}{ Waste } & \multirow[b]{2}{*}{ Comments on relevant waste reasons } & \multicolumn{3}{|c|}{ Data collection } \\
\hline Theoretical & Empirical & & 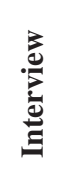 & 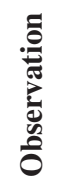 & 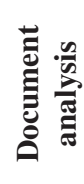 \\
\hline Waiting & $\begin{array}{l}\text { Waiting for the project to } \\
\text { be approved }\end{array}$ & $\begin{array}{l}\text { Incomplete service orders (project specifications), } \\
\text { lack of connectors sample or damaged connectors }\end{array}$ & $\mathrm{X}$ & $\mathrm{X}$ & $\mathrm{X}$ \\
\hline \multirow{3}{*}{ IT resource limitations } & Incompatibility problems & $\begin{array}{c}\text { Files from clients, with extensions, that are } \\
\text { incompatible with the software used in the } \\
\text { enterprise. }\end{array}$ & $\mathrm{X}$ & & \\
\hline & $\begin{array}{c}\text { Too much time wasted to } \\
\text { locate past projects in the } \\
\text { software }\end{array}$ & $\begin{array}{l}\text { In some projects, it was observed waste of time } \\
\text { trying to look for designs already done using the } \\
\text { enterprise software. }\end{array}$ & & $\mathrm{X}$ & \\
\hline & Process capacity & $\begin{array}{l}\text { It was necessary to send designs to the } \\
\text { headquarters, since the designs had not been } \\
\text { registered at GDM. }\end{array}$ & & & $\mathrm{X}$ \\
\hline Unnecessary movement & $\begin{array}{l}\text { Staff's excessive } \\
\text { movement }\end{array}$ & $\begin{array}{c}\text { Part of the resources (copies, physical files, CAM, } \\
\text { etc.) used in the PDP requires the employee to } \\
\text { move significantly from his workplace. }\end{array}$ & $\mathrm{X}$ & $\mathrm{X}$ & \\
\hline \multirow[t]{2}{*}{ Reinvention } & Poor reuse of knowledge. & $\begin{array}{c}\text { The formation of a company's designer is mainly } \\
\text { done on the job. However, the small number of } \\
\text { designers and the high number of projects does } \\
\text { not allow acquirement and socialization of the } \\
\text { knowledge generated. Moreover, the exchange } \\
\text { of knowledge among units in other countries } \\
\text { occurs informally when the designer is partially } \\
\text { allocated in other unit to meet the increasing } \\
\text { project demands. The corporative mechanism of } \\
\text { knowledge management is restricted to the project } \\
\text { records. }\end{array}$ & $\mathrm{X}$ & $\mathrm{X}$ & $\mathrm{X}$ \\
\hline & Poor reuse of projects. & $\begin{array}{c}\text { All projects are registered; however, its indexation } \\
\text { among plants in other countries was not present. } \\
\text { With the implementation of a unified database, } \\
\text { project duplication had a considerable reduction. } \\
\text { However, there are still projects that were not } \\
\text { registered. }\end{array}$ & $\mathrm{X}$ & $\mathrm{X}$ & $\mathrm{X}$ \\
\hline Defects & $\begin{array}{l}\text { Rework - Erroneous } \\
\text { information about projects }\end{array}$ & $\begin{array}{c}\text { Reworks found were due to erroneous information } \\
\text { such as tight silhouette, incompatible taps, } \\
\text { uncertainty of terminal alignments and bad } \\
\text { connector bracing. }\end{array}$ & $\mathrm{X}$ & $\mathrm{X}$ & $\mathrm{X}$ \\
\hline
\end{tabular}


Chart 2. Characterization of wastes identified in the case study.

\begin{tabular}{|c|c|c|c|c|c|}
\hline \multicolumn{2}{|c|}{ Wastes } & \multirow[b]{2}{*}{ Comments on relevant waste reasons } & \multicolumn{3}{|c|}{ Data collection } \\
\hline Theoretical & Empirical & & : & 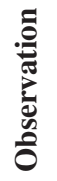 & 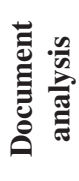 \\
\hline Transport & $\begin{array}{l}\text { Comings and goings of } \\
\text { tasks/ interrupted tasks }\end{array}$ & $\begin{array}{l}\text { When the production sector has questions regarding } \\
\text { the product project and goes to the PDP sector to solve } \\
\text { them, interrupting the designer's activity. At the end } \\
\text { of the development, the designers carry information to } \\
\text { the CAM sector. Much of the communication is direct, } \\
\text { although there are other means (records, documents, } \\
\text { telephone, e-mail, etc). Direct communication is } \\
\text { preferred for it is a small enterprise. }\end{array}$ & $X$ & $X$ & \\
\hline Inventory & $\begin{array}{l}\text { Waiting lines on the } \\
\text { critical path }\end{array}$ & $\begin{array}{l}\text { Waiting lines were identified in CAM sector in order } \\
\text { to develop projects and lines of projects for product } \\
\text { development. }\end{array}$ & $\mathrm{X}$ & $X$ & \\
\hline Over production & $\begin{array}{l}\text { Synchronism between the } \\
\text { developed time and the } \\
\text { planned time }\end{array}$ & $\begin{array}{l}\text { There is no synchronism between planned time for } \\
\text { development and the developed time used by the } \\
\text { enterprise designers. }\end{array}$ & $\mathrm{X}$ & & \\
\hline
\end{tabular}

productive system upon request. This fact can characterize the enterprise as an extreme case, as cited by Yin (2005), supporting the grounds for selecting this enterprise for the study. The PDP in EMDEP consists of the sales processes, project, and computer-aided manufacturing (CAM). The enterprise defines CAM for the area responsible for the computer design, corresponding partially to the product development process.

\subsection{Qualitative research}

In order to carry out the qualitative research, a semistructured interview was used, which was based on a research protocol (Chart 2). The research was performed with four interviewees from the project sector and one CAM member.

Charts 2 and 3 present the results from the interviews.

The results from the qualitative research showed that there were wastes in the process and that they helped the development and collection of information for the second quantitative method. From the 10 wastes surveyed in the literature, not all of them were identified. The limitation waste in the IT resources was found only in the project area. The other eight wastes surveyed were identified in two areas (project and CAM) and they may be mitigated. With the tool implementation, one might mitigate or eliminate those wastes.

\subsection{Quantitative research}

There are three kinds of holders, ordered by complexity level of pneumatic and mechanical projects and its
Chart 3. Wastes identified in the product development in the enterprise, which is the object of study.

\begin{tabular}{|l|c|c|}
\hline \multicolumn{1}{|c|}{ Wastes/ areas } & Design (Project) & CAM \\
\hline Waiting & $\mathrm{X}$ & $\mathrm{X}$ \\
\hline Transport & $\mathrm{X}$ & $\mathrm{X}$ \\
\hline Unnecessary movement & $\mathrm{X}$ & $\mathrm{X}$ \\
\hline Inadequate processes & $\mathrm{X}$ & $\mathrm{X}$ \\
\hline Inventory & $\mathrm{X}$ & $\mathrm{X}$ \\
\hline Overproduction & $\mathrm{X}$ & $\mathrm{X}$ \\
\hline Defects & $\mathrm{X}$ & $\mathrm{X}$ \\
\hline Reinvention & $\mathrm{X}$ & $\mathrm{X}$ \\
\hline Lack of discipline & $\mathrm{O}$ & $\mathrm{O}$ \\
\hline IT resource limitations & $\mathrm{X}$ & $\mathrm{O}$ \\
\hline
\end{tabular}

Legend: $\mathrm{X}$ - identified waste; $\mathrm{O}$ - Non-identified waste

assembling. They are different according to the kinds and complexity of the tests that are conducted in the wire harnesses. In order to determine the number of samples for each kind of holder, data from the amount of developed projects was collected for each kind of holder in 12 months. Boxplot from Minitab ${ }^{\circledR}$ version 14 was used to eliminate values that are out of the sample, as shown in Figure 1. The only real data that was eliminated was the value 763 from the pneumatic holder.

By eliminating this value to calculate the average value and the standard deviation, one has the average value and the standard deviation for each holder, Table 1.

PDP times were collected from the enterprise's Microsiga system database, once every PDP stage is 
recorded through a bar code system, the stage end and the start of the next stage.

For the data obtained, it was verified the distributions that best fit according to the designer and kind of holder, Table 2. For each kind of curve, it is necessary to define some of their features cited in parenthesis.

Obtaining and analyzing the project times (Table 2) permitted the identification of the kind of probability distribution with its respective quantification. These results were then, used in simulations. The values obtained through simulation replication prescribed as many quantities as the real ones. The time required for each simulation was 176 hours, due to the hourload used inside the enterprise in a month.

For the computational simulation, simulation input parameters were defined: probability distributions for each kind of holder, being that 176 hours is the time available for the development; replications carried out with the same real data amount for each kind of project.

Such simulation results of development time of holders for each type are described in Table 3. Thus, in the following

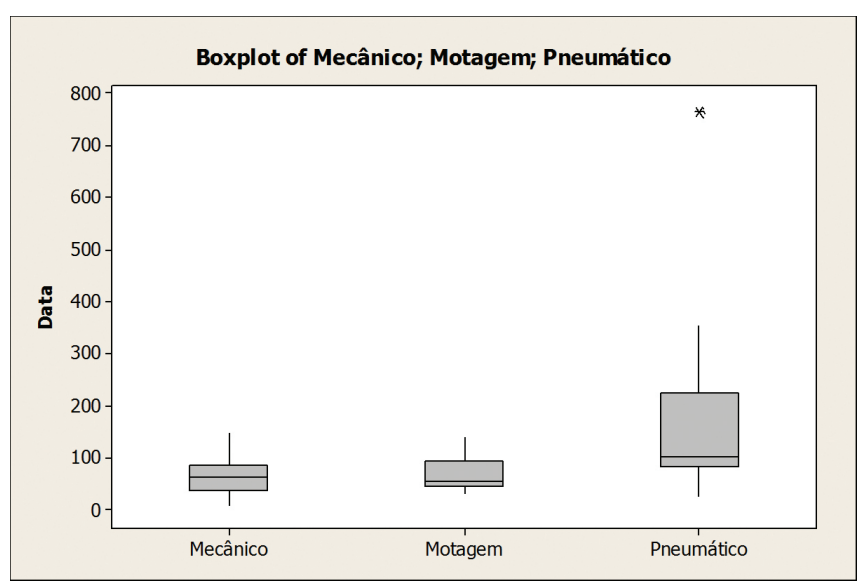

Figure 1. Boxplot for three models of holders.

Table 1. Average value and standard deviation of product of each kind of holder.

\begin{tabular}{|l|c|c|c|}
\hline & Pneumatic & Mechanical & Assembling \\
\hline Average value & 146,43 & 65,73 & 73,05 \\
\hline Standard deviation & 100,25 & 36,75 & 34,74 \\
\hline
\end{tabular}

Table 3, the standard deviations and average values for the simulations for each holder are:

\subsection{Simulated model}

Six PDP evolutive models of the enterprise were developed, where more details were incorporated to each model (Chart 4). The fifth model presented the PDP simulation in the real state and the sixth model presented the gains related to the number of produced holders that the enterprise has, by eliminating the PDP wastes.

Values presented in Table 4, were found in order to validate the simulated model using the formula [1], for each holder. The fifth model validation was quantitative, where results from simulation are compared statistically to the historical ones.

During the data collection of time waste, one of the designers was laid off for presenting designs below the average. Thus, it was necessary to perform the model simulation with waste elimination, using only three designers. In order to compare results before and after waste elimination, the simulation was redone considering only the three designers remaining. The PDP simulation results with wastes and the three designers are described in Table 5.

The collection of time waste data was carried out by the researcher's observation, and through the filling of specific forms by designers and CAM staff from February 22 to March 14, 2008. In one month, it was noted 16 hours and 20 seconds of time waste. This time was considered a gain for the enterprise in the simulation of data without wastes, considering that the elimination of this waste would result in the availability of designers to develop other projects. Therefore, it was added 16 hours to the simulated time in order to compare how many extra holders the enterprise would produce if there were no wastes. Thus, the total amount of time simulated, eliminating waste, was 192 hours. The PDP simulation without wastes and with the three designers is depicted in Table 6.

This validation allowed performing simulations of PDP gains, once wastes were eliminated.

\subsection{Data analysis}

The results obtained from the simulated model showed an improvement of product development when the wastes cited in the literature are eliminated or mitigated. This can

Table 2. Distribution used by the designer for each kind of holder.

\begin{tabular}{|c|c|c|c|}
\hline Designer & Pneumatic Holder distribution & Mechanical Holder distribution & Assembling Holder distribution \\
\hline Designer 01 & Weibull $(3 ; 0,409 ; 149)$ & Pearson $5(1,16 ; 0,757 ; 6,36)$ & Pearson $6(3,83 ; 0,597 ; 5 t, 83)$ \\
\hline Designer 02 & Exponential $(3 ; 38,1)$ & Pearson $5(-1,32 ; 1,56 ; 21,3)$ & Lognormal $(2,86 ; 2,33 ; 1,89)$ \\
\hline Designer 03 & Lognormal $(0,936 ; 3,92 ; 1,41)$ & Lognormal $(1,86 ; 3,08 ; 1,33)$ & Lognormal $(2,96 ; 2,64 ; 2,33)$ \\
\hline Designer 04 & Lognormal $(2,55 ; 3,18 ; 1,74)$ & Lognormal $(2,84 ; 2,93 ; 2,04)$ & Normal $(77,75 ; 99,79)$ \\
\hline CAM & Weibull $(4 ; 0,709 ; 168)$ & Pearson $5(-4,91 ; 1,05 ; 37,5)$ & Lognormal $(8,4 ; 4,24 ; 1,79)$ \\
\hline
\end{tabular}


Table 3. Average values and standard deviation for each kind of holder from simulations.

\begin{tabular}{|l|c|c|c|}
\hline & Pneumatic & Mechanical & Assembling \\
\hline Average value & 141,48 & 54,05 & 63,36 \\
\hline Standard deviation & 14,95 & 8,18 & 4,87 \\
\hline
\end{tabular}

be, statistically proved, by comparing the total amounts produced in the simulation of the PDP with and without waste, according to the values of Table 7, twenty-two replications were conducted in the simulated model.

The Levene test (Minitab $14^{\circledR}$ ) was performed to verify the equality of variances. It was considered, for this test, the

Chart 4. PDP evolutive models of EMDEP Brazil.

Mirst model: stream definition,
location, entities, processes and
arrivals.


Table 4. Simulated model validation for each kind of holder.

\begin{tabular}{|c|c|c|c|c|}
\hline & $\begin{array}{c}\text { Significance } \\
\text { level }\end{array}$ & $\begin{array}{c}\text { Simulated product } \\
\text { number }\end{array}$ & $\begin{array}{c}\text { Development time obtained by model simulation } \\
\text { (average value and standard deviation) }\end{array}$ & Validation result \\
\hline Mechanical Holder & $95 \%$ & 22 & $(-27,88 ; 4,52)$ & Validated \\
\hline Pneumatic Holder & $95 \%$ & 21 & $(-49,63 ; 39,83)$ & Validated \\
\hline Assembling Holder & $95 \%$ & 22 & $(-24,78 ; 5,4)$ & Validated \\
\hline
\end{tabular}

Table 5. Quantity of each holder produced through model simulation with three designers.

\begin{tabular}{|l|c|c|c|}
\hline & Pneumatic & Mechanical & Assembling \\
\hline Average value & 136,91 & 53,77 & 59,73 \\
\hline Standard deviation & 17,99 & 8,93 & 8,41 \\
\hline
\end{tabular}

Table 6. Quantity of each holder produced through model simulation with three designers and waste elimination.

\begin{tabular}{|l|c|c|c|}
\hline & Pneumatic & Mechanical & Assembling \\
\hline Average value & 152,45 & 62,45 & 67,55 \\
\hline Standard deviation & 17,27 & 8,19 & 7,31 \\
\hline
\end{tabular}

Table 7. Values for holders produced in the simulation with and without wastes.

\begin{tabular}{|c|c|}
\hline $\begin{array}{c}\text { Simulation values with } \\
\text { wastes }\end{array}$ & $\begin{array}{l}\text { Simulation values without } \\
\text { wastes }\end{array}$ \\
\hline 224 & 294 \\
\hline 291 & 253 \\
\hline 225 & 293 \\
\hline 263 & 280 \\
\hline 285 & 256 \\
\hline 252 & 262 \\
\hline 275 & 292 \\
\hline 233 & 278 \\
\hline 226 & 300 \\
\hline 240 & 288 \\
\hline 259 & 280 \\
\hline 251 & 292 \\
\hline 262 & 261 \\
\hline 256 & 325 \\
\hline 279 & 272 \\
\hline 247 & 303 \\
\hline 247 & 284 \\
\hline 206 & 272 \\
\hline 246 & 271 \\
\hline 216 & 281 \\
\hline 254 & 314 \\
\hline 272 & 263 \\
\hline
\end{tabular}

Null hypothesis (H0) and the alternative hypothesis (H1) for equal and non-equal variances, respectively.

The result obtained from the Levene test (Minitab $14^{\circledR}$ ) shows that variances in both sampling groups resulted in a p-value of 0.412 , higher than 0.05 , that is, null hypothesis for group variance equality.

The variances of the groups are equal. Thus, the twosample t test (Minitab $14^{\circledR}$ ) may be performed with a reliability interval of $95 \%$. This is done to compare average values in order to verify if there was effective enhancement in the PDP when process waste is eliminated.

For the two-sample $\mathrm{t}$ test, null ( $\mathrm{H} 0)$ and alternative (H1) hypothesis were used, considering equal and different average values, respectively.

The results show that with $95 \%$ reliability, the average values for holders produced with or without wastes have different averages for the p-value found was 0.00 , where equality was rejected.

Thus, by eliminating PDP wastes, the enterprise could develop $12.8 \%$ more holders projects.

\section{Conclusions}

The value stream mapping, a tool of the lean thinking in product development, detected wastes within the PDP in the enterprise studied; based on the analysis of a pilot case study of holders development.

Through value stream mapping application, supported by process researcher's observation, interviews with keyinformants and document analysis, it was possible to identify wastes of waiting, transport, unnecessary movement, inadequate processes, inventory, overproduction, defects, reinvention and IT resource limitations in the enterprise PDP. This answers the research questions concerning the research qualitative stage.

However, lack of discipline related waste, was not identified by the researcher during the research. One of the possible reasons for this was the fact that, the enterprise has the certification of its quality management system by the standard ISO 9001 (version 2000), and that the PDP is part of the scope. This suggests that the enterprises that have a quality management system certificate with a PDP reference model implemented; may show less lack of discipline waste in the PDP.

The implementation of the quantitative stage of the study, made it possible to verify, through computational simulation, that the elimination of PDP wastes could provide gains of the order of $12 \%$ the amount of holders produced. This finding led to the acceptance of the hypothesis of the quantitative stage of this research. 
The results from the present work suggest that the lean wastes occur as the result of performing the entire PDP, concerning that it was not possible to claim if there is a higher incidence of such waste at any specific stage of the PDP (project planning, conceptual design, detailed design, etc.)

With the waste causes identified and the construction of a PDP model that allowed its simulation, mechanisms were obtained. These mechanisms led to the decision-making process to optimize and enhance the PDP.

As recommendations for continuing research, we suggest a study to prioritize the lean tools in the lean thinking implementation in new product development. Propose performance indicators for measuring and monitoring the process of lean product development; identify and analyze the impact of PDP wastes on incubated technology-based enterprises; and to verify, wheather the wastes are influenced by the type of project (innovation, evolution, variation and reverse).

\section{Acknowledgements}

The authors thank the EMDEP, UNIFEI, CAPES Foundation, (Process PE024/2008), the FAPEMIG Foundation (Processes TEC-PPM-00043/08, PPM00586-11, TEC APQ-00976-13, PPM-00520-13, TECPPM-00058-13, and TEC APQ-5604-6.01/07) and the CNPq (Process 310660/2012-2 and 304628/2012-3), without their support, this work would be impossible. In addition, they thank the enterprise, study object, for offering useful conditions in order to conduct the research; and, finally, the interviewees, for their information, patience and devoted time for this work.

\section{References}

BACK, N. Metodologia de projeto de produtos industriais. Rio de Janeiro: Editora Guanabara Dois, 1983.

BAUCH, C. Lean Product Development: Making waste transparent. 2004. 140 f. Tese (Doutorado)-Technical University of Munich, Munich, 2004.

CHIANG, T.-A.; CHE, Z. H. A fuzzy robust evaluation model for selecting and ranking NPD projects using Bayesian belief network and weight-restricted DEA. Expert Systems with Applications, v. 37, n. 11, p. 7408-7418, 2010. http:// dx.doi.org/10.1016/j.eswa.2010.04.034

COOPER, R. G.; EDGETT, S. J. Product Development for de Service Sector - Lessons from market leaders. New York: Basic Books, 1999.

CRESWELL, J. W.; PLANO CLARK, V. L. Designing and conducting mixed methods research. California: Sage Publications, 2007. 265 p.
DEMETER, K.; MATYUSZ, Z. The impact of lean practices on inventory turnover. International Journal of Production Economics, v. 131, n. 1, p. 154-163, 2011. http://dx.doi. org/10.1016/j.ijpe.2009.10.031

DURMUŞOĞLU, S. S.; BARCZAK, G. The use of information technology tools in new product development phases: Analysis of effects on new product innovativeness, quality, and market performance. Industrial Marketing Management, v. 40, n. 2, p. 321-330, 2011. http://dx.doi. org/10.1016/j.indmarman.2010.08.009

FEARLE, A.; FOWLER, N. Efficiency versus effectiveness in construction supply chains: the dangers of "lean" thinking in isolation. Supply Chain Management: An International Journal, v. 11, n. 4, p. 283-287, 2006. http://dx.doi. org/10.1108/13598540610671725

GAVIRA, M. O. Simulação computacional como ferramenta de aquisição de conhecimento. 2003. Dissertação (Mestrado em Engenharia de Produção)-Universidade de São Paulo, São Carlos, 2003.

GREASLEY, A. Using business-process simulation within a business-process reengineering approach. Business Process Management Journal, v. 9, n. 4, p. 408-420, 2003. http:// dx.doi.org/10.1108/14637150310484481

HINES, P.; HOLWEG, M.; RICH, N. Learning to envolve. A review of contemporary lean thinking. International Journal of Operations \& Production Management, v. 24, n. 10, p. 994-1011, 2004. http://dx.doi. org/10.1108/01443570410558049

KARLSSSON, C.; AHISTRÖM, P. The difficult path to lean product development. Journal of product innovation management, v. 13, n. 4, p. 283-295, 1996. http://dx.doi. org/10.1016/S0737-6782(96)00033-1

KEMPTON, J. Can lean thinking apply to the repair and refurbishment of properties in the registered social landlord sector? Structural Survey, v. 24, n. 3, p. 201-211, 2006. http://dx.doi.org/10.1108/02630800610678850

KLEIJNEN, J. P. C. Verification and validation of simulation models. European Journal of operational Research, v. 82, p. 145-162, Apr 1995. http://dx.doi.org/10.1016/03772217(94)00016-6

LAW, A. M.; KELTON, W. D. Simulation modeling and analysis. 2nd ed. New York: McGraw Hill, 1991.

LOCH, C.; TERWIESCH, C. Handbook of New Product Development Management. Oxford: Elsevier-Butterworth/ Heineman, 2007.

MACHADO, M. C. Princípios enxutos no processo de desenvolvimento de produtos: proposta de uma metodologia para implementação. 2006. Tese (Doutorado)Universidade de São Paulo, São Paulo, 2006. 
OHNO, T. Toyota Production System: Beyond Large-Scale Production. Portland: Productivity Press, 1988.

PAÇO, T. R. Avaliação do uso de simulação como ferramenta complementar no desenvolvimento do mapeamento do fluxo de valor futuro. 2006. Dissertação (Mestrado)Universidade Federal de São Carlos, São Carlos, 2006.

PAHL, G. et al. Engineering Design: A Systematic Approach. 3 ed. Springer, 2007.

PANIZZOLO, R.; BIAZZO, S.; GARENGO, P. New product development assessment: towards a normative-contingent audit. Benchmarking: An International Journal, v. 17, n. 2, p. 173-194, 2010.

PAPADOPOULOS, T.; RADNOR, Z.; MERALI, Y. The role of actor associations in understanding the implementation of Lean thinking in healthcare. International Journal of Operations \& Production Management, v. 31, n. 2, p. 167191, 2011. http://dx.doi.org/10.1108/01443571111104755

PARK, Y. H. A study of risk management and performance measures on new product development. Asian Journal on Quality, p. 11, n. 1, p. 39-48, 2010.

PEREIRA, I. C. Proposta de sistematização da simulação para fabricação em lotes. 2000. Dissertação (Mestrado em Engenharia de Produção)-Universidade Federal de Itajubá, Itajubá, 2000.

PETERSEN, K.; WOHLIN, C. Software process improvement through the Lean Measurement (SPI-LEAM) method. The Journal of Systems and Software, v. 83, n. 7, p. 12751287, 2010. http://dx.doi.org/10.1016/j.jss.2010.02.005

ROSENTHAL, S. R. Effective Product Design and Development - How to cut lead-time and increase customer satisfaction. New York: Irwin Professional Publishing, 1992.

ROZENFELD, H. et al. Gestão de desenvolvimento de Produtos - Uma referência para a melhoria do processo. São Paulo: Editora Saraiva, 2006.

RUNDQUIST, J.; HALILA, F. Outsourcing of NPD activities: a best practice approach. European Journal of Innovation Management, v. 13, n. 1, p. 5-23, 2010. http://dx.doi. org/10.1108/14601061011013203

SAlGADO, E. G.; SALOMON, V. A. P.; MELlO, C. H. P. Analytic hierarchy prioritisation of new product development activities for electronics manufacturing. International Journal of Production Research, v. 50, n. 17 , p. 4860-4866, 2012. http://dx.doi.org/10.1080/0020 7543.2012.657972

SAMAAN, M. et al. Identificação dos fatores críticos de sucesso no desenvolvimento de produtos de empresas de biotecnologia do estado de Minas Gerais. Revista Produção, v. 22, p. 436-3-447, 2012.

SILVA, C. E. S. et al. Integration of computer simulation in design for manufacturing and assembly. International Journal of Production Research, p. 1-16, 2013. 10.1080/00207543.2013.853887

SARGENT, R. G. Validation and verification of simulation models. In: WINTER SIMULATION CONFERENCE, 2004. Proceedings... 2004.

SHINGO, S. A Study of the Toyota Production System from an Industrial Engineering Viewpoint. Productivity Press, 1996.

SOHAL, A. S.; EGGLESTONE, A. Lean production: experience among Australian organizations. International Journal of Operations \& Production Management, v. 14, n. 11, p. 3551, 1994. http://dx.doi.org/10.1108/01443579410068639

VINCENT, G. Managing new product development. New York: Van Nostrand Reinold, 1989. http://dx.doi. org/10.1007/978-1-4684-7502-9

WHEELWRIGHT, S. C.; CLARK, K. B. Revolutionizing product development - Quantum Leaps in Speed, Efficiency, and Quality. New York: Free Press, 1992.

WOMACK, J. P.; JONES, D. T.; ROOS, D. The machine that changed the world. New York: Rawson Associates, 1992.

WOMACK, P. J.; JONES, D. T. Lean thinking: Banish waste and create wealth in your corporation. New York: Simon \& Schuster, 1996.

WOMACK, P. J.; JONES, D. T. A mentalidade enxuta nas empresas - lean thinking - elimine o desperdício e crie riqueza. Rio de Janeiro: Campus, 2004.

YEH, T. M.; PAI, F. Y.; YANG, C. C. Performance improvement in new product development with effective tools and techniques adoption for high-tech industries. Quality and Quantity, v. 44, n. 1, p. 131-152, 2008. http://dx.doi. org/10.1007/s11135-008-9186-7

YIN, R. Estudo de caso. Planejamento e métodos. 3. ed. Porto Alegre: Bookman, 2005. 